Int. J. Environ. Res. Public Health 2008, 5(5) 428-435

International Journal of

Environmental Research and Public Health

ISSN 1661-7827

www.ijerph.org

(c) 2008 by MDPI

\title{
Assessment of the Efficacy of Chelate-Assisted Phytoextraction of Lead by Coffeeweed (Sesbania exaltata Raf.)
}

\author{
Gloria Miller, Gregorio Begonia*, Maria Begonia, Jennifer Ntoni and Oscar Hundley \\ Plant Physiology/Microbiology Laboratory, Department of Biology, P.O. Box 18540, College of Science, Engineering and \\ Technology, Jackson State University, 1000 Lynch Street, Jackson, Mississippi 39217, USA \\ *Correspondence to Dr. Gregorio Begonia. Email: gregorio.begonia@jsums.edu
}

Received: 20 September 2008 / Accepted: 08 December 2008 / Published: 31 December 2008

\begin{abstract}
Lead $(\mathrm{Pb})$, depending upon the reactant surface, $\mathrm{pH}$, redox potential and other factors can bind tightly to the soil with a retention time of many centuries. Soil-metal interactions by sorption, precipitation and complexation processes, and differences between plant species in metal uptake efficiency, transport, and susceptibility make a general prediction of soil metal bioavailability and risks of plant metal toxicity difficult. Moreover, the tight binding characteristic of $\mathrm{Pb}$ to soils and plant materials make a significant portion of $\mathrm{Pb}$ unavailable for uptake by plants. This experiment was conducted to determine whether the addition of ethylenediaminetetraacetic acid (EDTA), ethylene glycol tetraacetic acid (EGTA), or acetic acid (HAc) can enhance the phytoextraction of $\mathrm{Pb}$ by making the $\mathrm{Pb}$ soluble and more bioavailable for uptake by coffeeweed (Sesbania exaltata Raf.). Also we wanted to assess the efficacy of chelates in facilitating translocation of the metal into the above-ground biomass of this plant. To test the effect of chelates on $\mathrm{Pb}$ solubility, $2 \mathrm{~g}$ of $\mathrm{Pb}$-spiked soil $(1000 \mathrm{mg} \mathrm{Pb} / \mathrm{kg}$ dry soil) were added to each $15 \mathrm{~mL}$ centrifuge tube. Chelates (EDTA, EGTA, HAc) in a 1:1 ratio with the metal, or distilled deionized water were then added. Samples were shaken on a platform shaker then centrifuged at the end of several time periods. Supernatants were filtered with a $0.45 \mu \mathrm{m}$ filter and quantified by inductively coupled plasma-optical emission spectrometry (ICP-OES) to determine soluble $\mathrm{Pb}$ concentrations. Results revealed that EDTA was the most effective in bringing $\mathrm{Pb}$ into solution, and that maximum solubility was reached 6 days after chelate amendment. Additionally, a greenhouse experiment was conducted by planting Sesbania seeds in plastic tubes containing top soil and peat (2:1, v:v) spiked with various levels (0, 1000, $2000 \mathrm{mg} \mathrm{Pb} / \mathrm{kg}$ dry soil) of lead nitrate. At six weeks after emergence, aqueous solutions of EDTA and/or HAc (in a 1:1 ratio with the metal) or distilled deionized water were applied to the root zones. Plants were harvested at 6 days after chelate addition to coincide with the duration of maximum metal solubility previously determined in this study. Results of the greenhouse experiment showed that coffeeweed was relatively tolerant to moderate levels of $\mathrm{Pb}$ and chelates as shown by very slight reductions in root and no discernable effects on shoot biomass. Root $\mathrm{Pb}$ concentrations increased with increasing levels of soil-applied $\mathrm{Pb}$. Further increases in root $\mathrm{Pb}$ concentrations were attributed to chelate amendments. In the absence of chelates, translocation of $\mathrm{Pb}$ from roots to shoots was minimal. However, translocation dramatically increased in treatments with EDTA alone or in combination with HAc. Overall, the results of this study indicated that depending on the nature and type of $\mathrm{Pb}$-contaminated soil being remediated, the bioavailability and uptake of $\mathrm{Pb}$ by coffeeweed can be enhanced by amending the soil with chelates especially after the plants have reached maximum biomass.
\end{abstract}

Keywords: Lead, Phytoextraction, Sesbania exaltata, Chelates 


\section{Introduction}

Metals differ from other toxic substances in that they are neither created nor destroyed by humans. Nevertheless, utilization by humans influences the potential for health effects in at least two major ways: first by environmental transport such as anthropogenic contributions to air, water, food and soil; and second, by altering the speciation or biochemical form of the element. Lead, in particular, depending upon the reactant surface, $\mathrm{pH}$, redox potential, and other factors can bind tightly to the soil [1-3] with a retention time of 150 to 5000 years $[1,4]$.

In spite of the ever-growing number of toxic metalcontaminated sites, the most commonly used methods of dealing with heavy metal pollution are either the extremely costly process of excavation and reburial or simply isolation of the contaminated sites. Remediation costs in the U.S. have been estimated at $\$ 7$ billion to $\$ 8$ billion per year, approximately $35 \%$ of which involves remediation of metals [5].

Recently, heavy metal phytoextraction has emerged as a promising, cost-effective alternative to the conventional methods of remediation [6-10]. The objective of phytoextraction is to reduce heavy metal levels below regulatory limits within a reasonable time frame [7]. To achieve this objective, plants must accumulate high levels of heavy metals and produce high amounts of biomass [8-11]. Soil-metal interaction by sorption, precipitation, and complexation processes, and differences between plant species in metal uptake efficiency, transport, and susceptibility make a general prediction of soil metal bioavailability and risks of plant metal toxicity difficult [12]. Moreover, the tight binding characteristic of $\mathrm{Pb}$ to soils and plant materials make $\mathrm{Pb}$ especially challenging for phytoremediation [13].

Previous hydroponic studies revealed that uptake and translocation of heavy metals in plants are enhanced by increasing heavy metal concentration in the nutrient solution [14]. The bioavailability of heavy metals in the soil is therefore, of paramount importance for successful phytoextraction. Lead has limited solubility in soils, and its availability for plant uptake is minimal due to complexation or binding with organic and inorganic soil colloids, and precipitation as carbonates, hydroxides, and phosphates [15-18].

Studies have shown that chelates can not only desorb heavy metals from the soil matrix into soil solution [19], but can enhance the bioavailability of $\mathrm{Pb}$ for uptake by the plant. Also, it has been reported that chelate amendments may aid in moving the $\mathrm{Pb}$ that is sequestered in the xylem cell wall of the roots upwards and into the shoots [3, 2024]. Specifically, this study was conducted to determine whether amendments of chelates such as EDTA, EGTA or HAc can enhance the solubility of $\mathrm{Pb}$ and make it more bioavailable for root uptake. Also we wanted to assess the efficacy of chelates in facilitating translocation of the metal into the shoots of coffeeweed. Our aim in this study was not only to utilize a Pb-specific chelate, but to also apply it in a time-efficient manner so that we could harvest the plant during its peak phytoextraction period. In a practical field application, this could reduce the risk of water pollution due to chelates and/or chelate-metal complexes migrating from the soil. Results of this study will be used to help establish an optimal time frame for harvesting Sesbania exaltata after chelate amendment, thereby limiting the likelihood of exposure to grazing animals.

\section{Materials and Methods}

In order to minimize discrepancies in the experimental results that could arise from heterogeneous soil samples, a laboratory contaminated soil sample was used throughout this experiment so that we could create a test sample with consistent lead concentration and speciation, soil composition, contamination process, and contamination period.

Delta top soil and humus peat were air-dried to approximately $1-3 \%$ moisture content for $3-4$ days under greenhouse conditions. Top soil and peat were cleaned of debris using a 1-cm sieve. Soil was prepared by mixing sieved soil, and peat in a 2:1 volumetric proportions. Representative samples of the prepared soil mixture were sent to Mississippi State University Soil Testing Laboratory, Mississippi State, MS to determine its physical and chemical characteristics.

\section{Solubility Test and Chelate Selection}

To prepare lead-contaminated soil for the leadsolubility test, approximately $550 \mathrm{~g}$ of the dry, sieved delta topsoil, peat mixture $(2: 1 \mathrm{v} / \mathrm{v})$ were placed in a plastic Ziploc bag and amended with $1000 \mathrm{mg} \mathrm{Pb} / \mathrm{kg}$ dry soil mixture using lead nitrate. Deionized distilled water was added to each bag of soil mixture to adjust the soil moisture content to approximately 30\% field capacity. The bags of soil were left to equilibrate (age) on a laboratory bench in the greenhouse for six weeks. The bags were occasionally turned and mixed during the incubation period to ensure thorough mixing.

After incubation, $2 \mathrm{~g}$ of Pb-contaminated soil were placed into each $15 \mathrm{~mL}$ BD Falcon tube. The appropriate chelate (ethylenediaminetetraacetic acid [EDTA], ethylene glycol tetraacetic acid [EGTA], or acetic acid [HAc] in a 1:1 ratio with the metal) was added to each tube for a final volume of $10 \mathrm{~mL}$ (1:5 soil to chelate ratio). Deionized distilled water was used as a control. The soilchelate mixture was then agitated in a Classic C-1 platform shaker for $0,1,2,5,6$, and 7 days at room temperature. To ensure homogeneity, the mixture was shaken for 10 minutes for time 0 . At the end of each time period, the suspension was centrifuged at $5000 \mathrm{rpm}$ (Fisher Scientific Centrific ${ }^{\circledR}$ Centrifuge Model 225) with a 5-minute acceleration and 30-minute deceleration. The supernatant was then filtered through a Whatman $0.45 \mu \mathrm{m}$ filter paper and $\mathrm{Pb}$ contents of each filtrate were quantified using inductively coupled plasma-optical emission spectrometry (ICP-OES; Perkin Elmer Optima 3300 DV). 


\section{Greenhouse Experiment}

Plants were grown in the Jackson State University greenhouse to evaluate the effectiveness of soil-applied chelating agents in enhancing metal uptake by Sesbania exaltata. Lead-spiked soil for the greenhouse experiment was prepared similarly as previously described for the solubility test. Approximately $550 \mathrm{~g}$ of the dry, sieved delta topsoil, peat mixture $(2: 1 \mathrm{v} / \mathrm{v})$ were placed in a plastic Ziploc bag and amended with either 0, 1000, or $2000 \mathrm{mg} \mathrm{Pb} / \mathrm{kg}$ dry soil mixture using lead nitrate. The $\mathrm{Pb}$ concentrations were chosen to simulate a moderately contaminated soil. Deionized distilled water was added to the bags to adjust the soil moisture content to approximately 30\% field capacity. The bags of soil were left to age on a laboratory bench in the greenhouse for six weeks. The bags were occasionally turned and mixed during the aging period to ensure thorough mixing.

Sowing of seeds: In order to soften the seed coat, Sesbania seeds were placed in a beaker that had been filled with deionized distilled water and the water was heated to $40^{\circ} \mathrm{C}$. The heat was then turned off, and the seeds were left to soak in the water for 24 hours. To prepare planting tubes, brown Wipe-All paper towels were folded and pushed to the bottom of each $656 \mathrm{~mL}$ Deepot tube (Stuewe and Sons, Inc., Corvallis, OR). The holes on the sides and at the bottom of the tubes were then wrapped with parafilm to prevent water from leaching from the bottom of the tube and to allow aeration at the root zone. Each Deepot tube was then filled with $550 \mathrm{~g}$ of the appropriate Pb-spiked soil mixture (0, 1000, $2000 \mathrm{mg}$ $\mathrm{Pb} / \mathrm{kg}$ dry soil) and 6 pre-soaked Sesbania seeds were planted and watered with $20 \mathrm{~mL}$ deionized distilled water.

Plant establishment and maintenance: Plants were irrigated every 2 days with $20 \mathrm{~mL}$ of either deionized distilled water or with a modified [23] Hoagland's nutrient solution ( $\mathrm{pH}$ 6.5) which contained the following nutrients in $\mathrm{mM}: \mathrm{NH}_{4} \mathrm{NO}_{3}, 5 ; \mathrm{K}_{2} \mathrm{SO}_{4}, 1.25 ; \mathrm{CaCl}_{2} .2 \mathrm{H}_{2} \mathrm{O}, 2.0$; $\mathrm{MgSO}_{4} .7 \mathrm{H}_{2} \mathrm{O}, 0.5 ; \mathrm{K}_{2} \mathrm{HPO}_{4}, 0.15 ; \mathrm{CaSO}_{4} .2 \mathrm{H}_{2} \mathrm{O}, 6.0$; the following in $\mu \mathrm{M}: \mathrm{H}_{3} \mathrm{BO}_{3}, 2.3 ; \mathrm{MnSO}_{4} . \mathrm{H}_{2} \mathrm{O}, 0.46$; $\mathrm{ZnSO}_{4} .7 \mathrm{H}_{2} \mathrm{O}$, 0.6; $\mathrm{CuSO}_{4} .5 \mathrm{H}_{2} \mathrm{O}, 0.15 ; \mathrm{NaMoO}_{4} .2 \mathrm{H}_{2} \mathrm{O}$, 0.10 ; $\mathrm{CoCl}_{2} .6 \mathrm{H}_{2} \mathrm{O}, 10.0$; and $20 \mathrm{mg} / \mathrm{L}$ Fe sequestrene. A 250- $\mathrm{mL}$ plastic cup was placed under each tube for leachate collection and to prevent cross contamination among treatments. Any leachate collected in each plastic cup was poured back into its corresponding tube. Periodically, these cups were rinsed with deionized distilled water and the resulting washing solutions were poured back into the respective tubes. The volume of water and/or nutrient solution ensured that soil moisture content was maintained at field capacity. Plants were maintained in a naturally-lit greenhouse throughout the experimental period. Emerged seedlings were thinned out to a desired population density of 2 plants per tube at 5 days after emergence.

Ethylenediaminetetraacetic acid (1:1 ratio with the $\mathrm{Pb}$ ) was applied as $100 \mathrm{~mL}$ aqueous solution 6 weeks after emergence. One hundred $\mathrm{mL}$ aqueous HAc solutions were also added to some treatments immediately after
EDTA applications. This experiment consisted of twelve treatments, arranged in a randomized complete block design (RCBD) with 2 plants per tube replicated 4 times for each harvesting period $(0,6$, and 7 days after chelate amendment).

During harvest, shoots and roots were separated, and roots were washed with distilled water to remove any adhering debris, then oven-dried in a Thelco convection oven at approximately $75^{\circ} \mathrm{C}$ for at least 48 hours.

\section{Metal Extraction and Analyses}

Dried samples were weighed and ground in a Wiley mill equipped with a $425 \mu \mathrm{m}$ (40-mesh) screen. Lead contents were extracted using EPA test method 3040B with slight modifications. Briefly, $40 \mathrm{ml}$ of $50 \%$ aqueous nitric acid were added to a $250 \mathrm{~mL}$ Erlenmeyer flask containing a representative sample of ground plant tissue. The acidified sample was heated to $35^{\circ} \mathrm{C}$, refluxed for 15 minutes without boiling, and then allowed to cool. Another $10 \mathrm{~mL}$ of $50 \%$ aqueous nitric acid were added and the sample was again heated and refluxed without boiling. To initiate the peroxide reaction, $2 \mathrm{~mL}$ of deionized distilled water and $3 \mathrm{~mL}$ of $30 \%$ hydrogen peroxide were added to the concentrated digestate and heated until effervescence subsided. Another $7 \mathrm{~mL}$ of $30 \%$ hydrogen peroxide were added continuously in $1 \mathrm{~mL}$ aliquots as the digestate was again heated. The digestate was heated until effervescence was minimal and its volume reduced to approximately $5 \mathrm{~mL}$. After cooling, the final digestate was diluted to approximately $15 \mathrm{~mL}$ with deionized water. The digestate was filtered through a filter paper (Whatman No. 1) and the final volume was adjusted to $25 \mathrm{~mL}$ with deionized, distilled water.

Lead concentrations were quantified using Inductively Coupled Plasma-Optical Emission Spectrometry [ICP-OES; Perkin Elmer Optima 3300 DV] and expressed as $\mu \mathrm{g} \mathrm{Pb} / \mathrm{g}$ dry weight of plant tissue.

\section{Statistical Analyses}

The solubility test and chelate selection experiment consisted of 4 treatments replicated 3 times for each time period $(0,1,3,5,6$, and 7 days). The greenhouse experiment consisted of 2 plants per tube, replicated 4 times for each of 3 harvesting periods (0, 6, and 7 days after chelate amendment). Data were analyzed using Statistical Analysis System (SAS V9). Treatment comparisons were done using Fisher's Protected Least Significant Difference (LSD) test. A probability of less than 5\% ( $p<0.05)$ was considered to be statistically significant.

\section{Results and Discussion}

For soil remediation initiatives, it is important to characterize both the chemical and physical parameters of the soil. Composition (e.g., nutrients, organic and inorganic materials), and soil mixture may all influence how the 
contaminant will behave. In general, in can be concluded that the chemistry of metal interaction with soil matrix is central to the phytoremediation concept. While the soil used in this study was high in phosphorus, potassium, and magnesium, these were nonetheless essential plant nutrients. Results of the soil analysis by Mississippi State University Soil Testing Laboratory are summarized in Table 1, and showed that the parameters of the soil used in this study were well within limits for our objectives.

Table 1: Physical and chemical characteristics of the soil

\begin{tabular}{lr}
\hline Characteristic & Extractable Levels (lbs/acre) \\
\hline Soil Acidity (pH) & 6.3 \\
Phosphorus & $130^{*}$ \\
Potassium & $301^{*}$ \\
Calcium & 4537 \\
Magnesium & $726^{* *}$ \\
Zinc & $4.2^{*}$ \\
Sodium & 161 \\
CEC & 17.6 \\
\% Clay & 7.50 \\
\% Silt & 80.08 \\
\% Sand & 12.4 \\
High* & \\
Very High** & \\
\hline
\end{tabular}

\section{Solubility Test and Chelate Selection}

Results of ICP-OES analyses revealed that among the chelates tested (EDTA, EGTA, and HAc), EDTA was the most effective in solubilizing soil-bound $\mathrm{Pb}$ (Fig. 1). Lead concentrations in soil solution increased with extraction time and remained constant 6 to 7 days after chelate amendment.

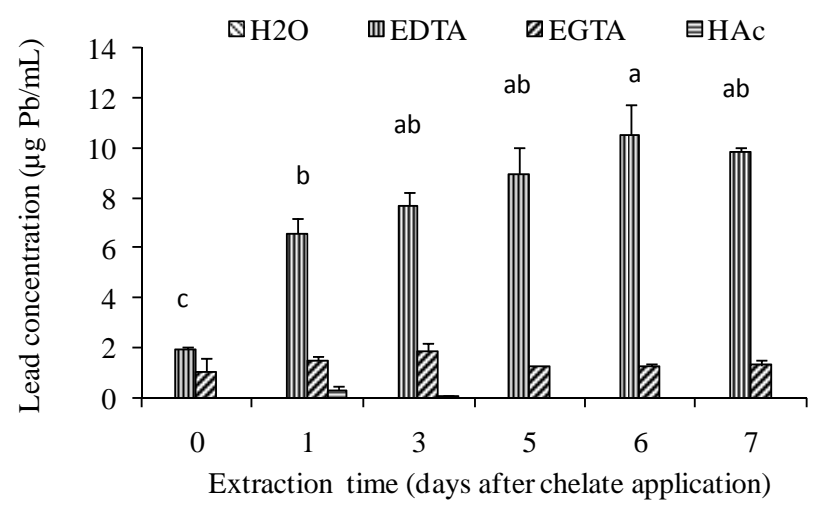

Figure 1: Lead solubility at various times after chelates application. Values and error bars represent means and standard errors of 3 replicates. Treatments with common letters do not differ significantly (Fisher's LSD, p < 0.05). Values not shown for a given extraction time indicates that $\mathrm{Pb}$ was not detected.
After 6 days, $\mathrm{Pb}$ concentration in soil solution of the EDTA-treated soil was $10.53 \mu \mathrm{g} \mathrm{Pb} / \mathrm{mL}$, as compared to 1.057, 0.047, and $0.048 \mu \mathrm{g} \mathrm{Pb/mL}$ for EGTA, HAc, and $\mathrm{H}_{2} \mathrm{O}$, respectively. These findings are consistent with those reported by Shen and his colleagues [25], who found that the Pb-concentration in soil solution of the EDTAtreated soil was 42-fold higher than that of the control soil, and that citric acid application to the soil produced only a small increase in the $\mathrm{Pb}$ concentration of soil solution and used by itself was much less effective than other chelates used.

We hypothesized that the efficacy of EDTA in solubilizing $\mathrm{Pb}$ from the soil may be related to the high binding capacity of EDTA for $\mathrm{Pb}$ as shown in previous studies [3, 20]. It may also be presumed that EGTA and HAc are more rapidly degraded than EDTA. Our aim in the solubility study was not only to utilize a Pb-specific chelate, but to also apply it in a time-efficient manner so that we could harvest the plant during its peak phytoextraction period. In a practical field application, this would reduce the likelihood of herbivores eating the contaminated plants, as well as limit the risk of water pollution due to chelates and/or chelate-metal complexes migrating from the soil.

\section{Greenhouse Experiment}

Lead-tissue concentration: Lead taken up by plants is usually increased with $\mathrm{Pb}$ concentrations in soil [26, 27]. Lead concentrations in root tissues were highest at 2000 $\mathrm{mg} \mathrm{Pb} / \mathrm{kg}$, with EDTA alone or in combination with HAc (Fig. 2).

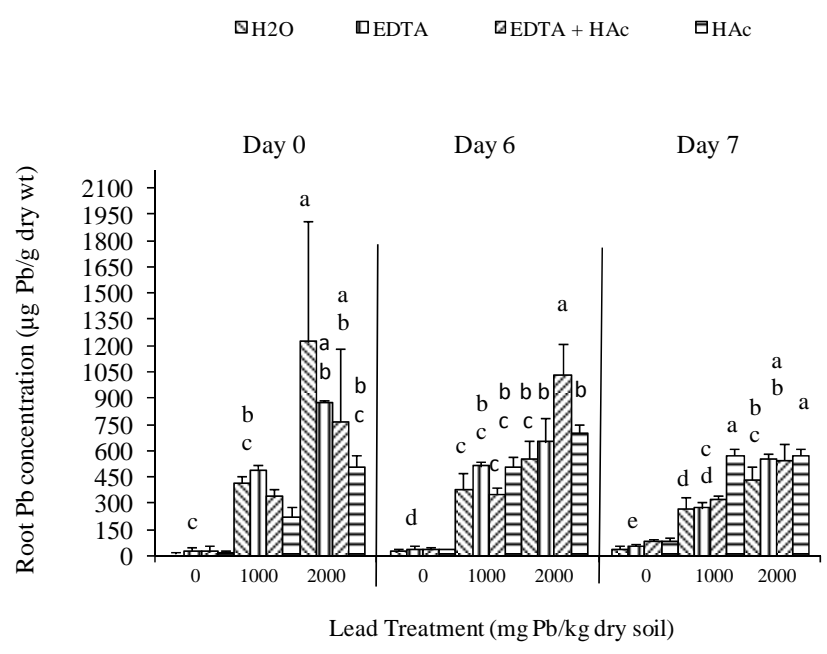

Figure 2: Effects of lead and chelates on root $\mathrm{Pb}$ concentrations ( $\mu \mathrm{g} \mathrm{Pb} / \mathrm{g}$ dry wt) of Sesbania exaltata Raf. at different days $(0,6,7)$ after chelate application. Chelates were applied at 6 weeks after seedling emergence. Values and error bars represent means and standard errors of 4 replicates. Treatments with common letters do not differ significantly from other treatments within the same time period (Fisher's LSD $p<0.05$ ). 
Also, $\mathrm{Pb}$ concentrations were higher for day 6 than for day 7. When no chelates were applied, shoot $\mathrm{Pb}$ concentrations slightly increased with increasing levels of soil-applied $\mathrm{Pb}$. This could be due to $\mathrm{Pb}$ binding to ion exchangeable sites on the cell wall and extracellular deposition mainly in the form of $\mathrm{Pb}$ carbonates deposited on the cell wall as previously demonstrated [28]. Lead being a soft Lewis acid, forms a strong covalent bond not only with the soil, but with plant tissues as well [20]. It is believed that since the xylem cell walls have a high cation exchange capacity, the upward movement of metal cations are severely retarded [10].

In the absence of chelates $\mathrm{Pb}$ concentration in shoots of coffeeweed plants grown at 1000 and $2000 \mathrm{mg} \mathrm{Pb} / \mathrm{kg}$ were minimal (Fig. 3). With the addition of chelates alone or in combination with HAc, translocation significantly increased in day 0 and day 6 . With the addition of chelates, it appeared that not only did the roots absorb more lead, but the metal was translocated to the shoots, facilitating some of the desirable characteristics of a hyperaccumulator, such as a high metal uptake by the roots, and translocation of the metal from the root to the above ground shoots. By day 7, however, there was not only a decline in the translocation of $\mathrm{Pb}$ to the shoots, but the decline was significantly lower in the $2000 \mathrm{mg} \mathrm{Pb} / \mathrm{kg}$ treatments as compared to $1000 \mathrm{mg} \mathrm{Pb} / \mathrm{kg}$ treatments.

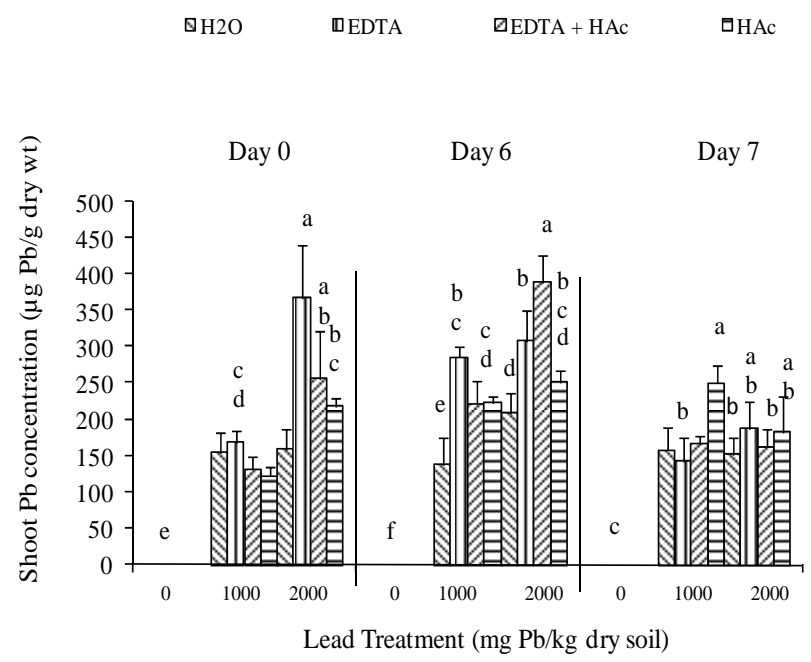

Figure 3: Effects of lead and chelates on shoot $\mathrm{Pb}$ concentrations ( $\mu \mathrm{g} \mathrm{Pb} / \mathrm{g}$ dry wt.) of Sesbania exaltata Raf. at different days $(0,6,7)$ after chelate application. Chelates were applied at 6 weeks after seedling emergence. Values and error bars represent means and standard errors of 4 replicates. Treatments with common letters do not differ significantly from other treatments within the same time period (Fisher's LSD $p<0.05$ ).

Table 2: Effects of lead and chelates on root dry biomass of Sesbania exaltata Raf. at 0, 6, and 7 days after chelate application

\begin{tabular}{|c|c|c|c|c|c|c|c|c|c|c|c|c|c|}
\hline \multirow{3}{*}{$\begin{array}{l}\text { Treatment } \\
\mathrm{Pb}(\mathrm{mg} / \mathrm{kg})\end{array}$} & \multirow[b]{3}{*}{ EDTA } & \multicolumn{12}{|c|}{ Root Dry Biomass (mg/plant) } \\
\hline & & \multicolumn{4}{|c|}{ Day 0} & \multicolumn{4}{|c|}{ Day 6} & \multicolumn{4}{|c|}{ Day 7} \\
\hline & & Mean & $* *$ & \pm & SEM & Mean & $* *$ & \pm & SEM & Mean & $* *$ & \pm & SEM \\
\hline 0 & 0 & 15.12 & c & \pm & 5.2 & 34.37 & c & \pm & 1.7 & 34.00 & $a b$ & \pm & 1.9 \\
\hline 0 & 1000 & 20.25 & abc & \pm & 6.9 & 37.50 & bc & \pm & 6.4 & 29.62 & $a b$ & \pm & 3.2 \\
\hline 0 & $1000 *$ & 19.87 & abc & \pm & 4.7 & 36.62 & bc & \pm & 7.1 & 31.37 & $a b$ & \pm & 6.7 \\
\hline 0 & HAc & 15.75 & $a b c$ & \pm & 5.4 & 34.50 & C & \pm & 5.8 & 27.75 & $\mathrm{~b}$ & \pm & 7.8 \\
\hline 1000 & 0 & 16.25 & $\mathrm{abc}$ & \pm & 2.0 & 36.12 & bc & \pm & 5.0 & 38.37 & $\mathrm{ab}$ & \pm & 6.7 \\
\hline 1000 & 1000 & 17.87 & $a b c$ & \pm & 3.9 & 41.52 & abc & \pm & 8.5 & 26.50 & $\mathrm{ab}$ & \pm & 3.5 \\
\hline 1000 & $1000 *$ & 24.12 & $a b c$ & \pm & 4.4 & 47.00 & abc & \pm & 1.9 & 40.50 & $a b$ & \pm & 2.1 \\
\hline 1000 & HAc & 23.62 & $a b c$ & \pm & 3.4 & 49.87 & $a b$ & \pm & 3.3 & 41.25 & $\mathrm{ab}$ & \pm & 8.8 \\
\hline 2000 & 0 & 29.75 & $\mathrm{a}$ & \pm & 3.6 & 51.00 & $a b$ & \pm & 6.4 & 48.12 & $\mathrm{a}$ & \pm & 5.3 \\
\hline 2000 & 2000 & 24.25 & abc & \pm & 3.7 & 42.37 & abc & \pm & 3.6 & 47.12 & $\mathrm{a}$ & \pm & 7.2 \\
\hline 2000 & $2000 *$ & 21.87 & $a b c$ & \pm & 6.4 & 53.50 & $\mathrm{a}$ & \pm & 5.7 & 47.37 & $\mathrm{a}$ & \pm & 8.7 \\
\hline 2000 & HAc & 28.87 & $\mathrm{a}$ & \pm & 3.1 & 45.87 & abc & \pm & 3.6 & 40.83 & $a b$ & \pm & 11.1 \\
\hline
\end{tabular}

Aqueous solutions of EDTA and HAc were applied alone or in combination in a 1:1 ratio with $\left[\mathrm{Pb}\left(\mathrm{NO}_{3}\right)_{2}\right]$ six weeks after seedling emergence. Plants were harvested at 0,6 , and 7 days after chelate application. *Indicates that HAc was added following EDTA amendment. SEM $=$ standard error of the mean of 4 replications. $* *$ Means followed by a common letter are not significantly different from other treatments within the same harvesting period $(p<0.05)$. 
Table 3: Effects of lead and chelates on shoot dry biomass of Sesbania exaltata Raf. at 0, 6,and 7 days after chelate application

\begin{tabular}{|c|c|c|c|c|c|c|c|c|c|c|c|c|c|}
\hline \multicolumn{6}{|l|}{ Treatment } & \multicolumn{8}{|c|}{ Shoot Dry Biomass (mg/plant) } \\
\hline \multirow{2}{*}{$\mathrm{Pb}(\mathrm{mg} / \mathrm{kg})$} & \multirow{2}{*}{ EDTA } & \multicolumn{4}{|c|}{ Day 0} & \multicolumn{4}{|c|}{ Day 6} & \multicolumn{4}{|c|}{ Day 7} \\
\hline & & Mean & $* *$ & \pm & SEM & Mean & $* *$ & \pm & SEM & Mean & $* *$ & \pm & SEM \\
\hline 0 & 1000 & 190.75 & a & \pm & 47.65 & 146.75 & abc & \pm & 27.3 & 114.75 & $\mathrm{~b}$ & \pm & 8.9 \\
\hline 0 & $1000 *$ & 143.75 & $\mathrm{a}$ & \pm & 18.0 & 141.38 & bc & \pm & 14.1 & 374.13 & $\mathrm{a}$ & \pm & 25.94 \\
\hline 1000 & 0 & 128.38 & $\mathrm{a}$ & \pm & 24.9 & 100.88 & C & \pm & 19.2 & 140.50 & $\mathrm{ab}$ & \pm & 30.3 \\
\hline 1000 & 1000 & 145.00 & $\mathrm{a}$ & \pm & 9.0 & 220.13 & $\mathrm{a}$ & \pm & 68.9 & 163.75 & $\mathrm{ab}$ & \pm & 15.6 \\
\hline 1000 & $1000^{*}$ & 187.75 & $\mathrm{a}$ & \pm & 33.7 & 167.0 & abc & \pm & 18.6 & 143.50 & $\mathrm{ab}$ & \pm & 25.0 \\
\hline 1000 & HAc & 191.38 & $\mathrm{a}$ & \pm & 16.6 & 189.63 & ab & \pm & 6.1 & 152.88 & $\mathrm{ab}$ & \pm & 30.2 \\
\hline 2000 & $2000 *$ & 140.38 & $\mathrm{a}$ & \pm & 15.7 & 186.25 & $\mathrm{ab}$ & \pm & 15.6 & 178.50 & $\mathrm{ab}$ & \pm & 23.4 \\
\hline 2000 & HAc & 190.38 & $\mathrm{a}$ & \pm & 18.0 & 158.0 & abc & \pm & 16.7 & 207.83 & $\mathrm{ab}$ & \pm & 73.3 \\
\hline
\end{tabular}

Aqueous solutions of EDTA and HAc were applied alone or in combination in a 1:1 ratio with $\left[\mathrm{Pb}\left(\mathrm{NO}_{3}\right)_{2}\right]$ six weeks after seedling emergence. Plants were harvested at 0,6 , and 7 days after chelate application. *Indicates that HAc was added following EDTA amendment. SEM = standard error of the mean of 4 replications. **Means followed by a common letter are not significantly different from other treatments within the same harvesting period $(p<0.05)$.

Our results are comparable with experiments by other investigators who have reported that bringing the $\mathrm{Pb}$ into solution with a chelating agent, not only makes more $\mathrm{Pb}$ bioavailable for root uptake [10, 20, 29], but also moves the $\mathrm{Pb}$ that is sequestered in the xylem cell wall upwards and into the shoots. Blaylock [3] demonstrated with Indian mustard (Brassica juncea (L.), and Huang et al. [20] demonstrated with peas (Pisum sativum L.) and corn (Zea mays L.) that the addition of EDTA to Pbcontaminated soil increased the shoot $\mathrm{Pb}$ concentrations by 300-fold, 111-fold, and 57-fold, respectively. Transport across root cellular membrane is an important process which initiates metal absorption into plant tissues. Several studies have shown that sequestration in root vacuole may prevent the translocation of some metals from root to shoot [30] whereas in hyperaccumulating plants, the mechanism of vacuolar sequestration may be disabled, allowing metal translocation and hyperaccumulation in leaves [30]. Therefore, it is generally agreed that the ability of plants to move the $\mathrm{Pb}$ upwards into the shoots varies much more than their ability to accumulate metals in the roots [29, 31].

Biomass: The capacity of plants to remove contaminants from the soil is a function of biomass per unit area and concentration of the contaminant in the plants [32]. Lead is not considered to be an essential element for plant growth and development, rather $\mathrm{Pb}$ inhibits growth, reduces photosynthesis (by inhibiting enzymes unique to photosynthesis), interferes with cell division and respiration, reduces water absorption and transpiration, accelerates abscission or defoliation and pigmentation, and reduces chlorophyll and adenosine triphosphate (ATP) synthesis [33]. At maturity, metalenriched aboveground biomass is harvested and a fraction of soil metal contamination removed [29, 34, 35].

Our results revealed that root biomass was not significantly different across the treatments. However, roots that were grown in $0 \mathrm{mg} \mathrm{Pb} / \mathrm{kg}$ soil had the lowest biomass, followed by treatments of $1000 \mathrm{mg} \mathrm{Pb} / \mathrm{kg}$ soil. The highest root biomass was seen in treatments of 2000 $\mathrm{mg} \mathrm{Pb} / \mathrm{kg}$ soil (Table 2). Shoot biomass followed the trend of root biomass. For each harvesting period $(0,6$, and 7 days) shoots that were grown in the highest lead treatments (2000 mg Pb/kg soil) alone or in combination with chelates had the highest biomass (Table 3). It is known that metal phytotoxicity causes stress to the plant resulting in a reduction in biomass and eventual death (in some cases). However, we observed no discernible phytotoxic symptoms in neither roots nor shoots. We concluded from this study and from earlier studies [24] that Sesbania may be tolerant to Pb-EDTA complex. Vassil et al. [21] demonstrated with Indian mustard that EDTA appears to chelate Pb outside of the plant, and then the soluble Pb-EDTA complex is transported through the plant, via the xylem, and accumulates in the leaves. Further, they found that toxicity symptoms in Indian mustard exposed to $\mathrm{Pb}$ and EDTA were strongly correlated with the presence of free protonated EDTA in solution.

Another explanation for the apparent metal tolerance seen in Sesbania may be the presence of natural metalbinding peptides. Cunningham and Ow [2] described the presence of specific high-affinity ligands as one of the metal-resistant mechanisms existing in some plants. 
These ligands, known as phytochelatins and metallothioneins, are reported to make the metal less toxic to the plant [36, 37]. We are not certain whether this resistance mechanism may exist in Sesbania, however, corollary studies regarding the relationship between $\mathrm{Pb}$ uptake and phytochelatin synthesis in coffeeweed are being investigated in our laboratory.

Results of this study indicated that EDTA can be applied to selected $\mathrm{Pb}$-contaminated soils in a timeefficient manner so that plants can be harvested during their peak phytoextractive period, thereby limiting the likelihood of exposure to herbivores as well as reducing the risk of water pollution due to chelates and /or chelatemetal complexes migrating from the soil.

Acknowledgements: This research was made possible through support provided by NASA to Jackson State University through the University of Mississippi under the term of Grant No. NNG05G572H/08-08012/300112306A. Partial research support to J.N. was provided by the U.S. Department of Education (Title III Program Grant No. P031B040101-07). Undergraduate fellowship to O.H. was provided by the Science and Technology Access to Research and Graduate Education (STARGE) Program. The opinions expressed herein are those of the authors and do not necessarily reflect the views of NASA or The University of Mississippi. Thanks to Christian Rogers, CSET Environmental Toxicology Core Laboratory for his technical assistance with metal analyses.

\section{References}

1. Kumar, P. B. A. N.; Dushenkov, V.; Motto, H.; Raskin, I.: Phytoextraction: The use of plants to remove heavy metals from soils. Environ. Sci. Technol. 1995, 29, (5), 1232-1238.

2. Cunningham, S. D.; Ow, W. D. Promises and prospects of phytoremediation. Plant Physiology, 1996, 110, 715-719.

3. Blaylock, M. J.; Salt, D. E.; Dushenkov, S.; Zakharova, O.; Gussman, C.; Kapulnik, Y.; Ensley, B. D.; Raskin, I. Enhanced accumulation of $\mathrm{Pb}$ in Indian mustard by soil-applied chelating agents. Environ. Sci. Technol. 1997, 31, (3), 860-865.

4. Friedland, A. J.: Heavy metal tolerance in plants: Evolutionary aspects. In Shaw, A. J., Ed. CRC Press: Boca Raton, FL, 1990.

5. Glass, D. J.: Economic potential of phytoremediation. In Phytoremediation of toxic metals: Using plants to clean up the environment. Raskin, I.; Ensley, D. D., Eds. John Wiley \& Sons, Inc.: New York, 2000; pp 1-14.

6. McGrath, S. P.; Sidoli, C. M. D.; Baker, A. J. M.; Reeves, R. D.: The potential for the use of metalaccumulating plants for the in situ decontamination of metal-polluted soils. In Integrated soil sediment research: A basis for proper protection, Eijascker, $\mathrm{H}$. J. P.; Hamers, T., Eds. Academic Publ: Dordrecht, Netherlands, 1993; pp 673-677.
7. Raskin, I.; Kumar, P. B. A. N.; Dushenkov, V.; Salt, D. E.: Bioconcentration of heavy metals by plants. Current Opinions in Biotechnology 1994, 5, 285-290.

8. Chaney, R. L.; Malik, M.; Li, Y. M.; Brown, S. L.; Brewer, E. P.; Angle, J. S.; Baker, A. J. M.: Phytoremediation of soil metals. Curr. Opin. Biotechnol. 1997, 8, (279-284).

9. Salt, D. E.; Blaylock, M.; Kumar, P. B. A. N.; Sushenkov, V.; Ensley, B. D.; Chet, I.; Raskin, I.: Phytoremediation: A novel strategy for the removal of toxic metals from the environment using plants. Biotechnology 1995, 13, 468-475.

10. Salt, D. E.; Smith, R. D.; Raskin, I. Phytoremediation. Annu. Rev. Plant Physiol. Plant Mol. Biol. 1998, 49, 643-668.

11. Shen, Z. G.; Zhao, E. J.; McGrath, S. P. Uptake and transport of zinc in the hyperaccumulator Thlaspi caerulescens and the nonhyperaccumulator Thlaspi ochroleucum. Plant Cell Environment 1997, 20, 898906.

12. Keltjens, W. G.; van Beusichem, M. L. Phytochelatins as biomarkers for heavy metal toxicity in maize: Single metal effects of copper and cadmium. J. Plant Nutr. 1998, 21, (4), 635 - 648.

13. Lim, T. T.; Tay, J. H.; Wang, J. Y.: Chelating-agentenhanced heavy metal extraction from a contaminated acidic soil. J. Environ. Eng. 2004, 130, 59 - 66.

14. Ghosh, S.; Rhyne, C.: Influence of EDTA on $\mathrm{Pb}$ uptake in two weed species, Sesbania and Ipomoea, in hydroponic culture. J. Miss. Acad. Sci. 1999, 44, (1), 11.

15. McBride, M. B.: Environmental chemistry of soils. Oxford University Press: 1994.

16. Kinniburgh, D. G.; Jackson, M. L.; Syers, J. K. Adsorption of alkaline-earth, transition, and heavymetal cations by hydrous oxide gels of iron and aluminum. Soil Science Society American Journal 1976, 40, 796-799.

17. Ruby, M. V.; Schoof, R.; Brattin, W.; Goldade, M.; Post, G.; Harnois, M.; Mosby, D. E.; Casteel, S. W.; Berti, W.; Carpenter, M.; Edwards, D.; Cragin, D.; Chappell, W.: Advances in evaluating the oral bioavailability of inorganics in soil for use in human health risk assessment. Environ. Sci. Technol. 1999, 32, 3697-3705.

18. Grcman, H.; Vodnik, D.; Velikonja-Bolta, S.; Lestan, D.: Heavy metals in the environment: Ethylenediaminedissuccinate as a new chelate for environmentlaly safe enhanced lead phytoextraction. J. Environ. Qual. 2003, 32, 500-506.

19. Jorgensen, S. E.: Removal of heavy metals from compost and soil by ecotechnological methods. Ecol. Eng. 1993, 2, 89-100.

20. Huang, J. W.; Chen, J.; Berti, W. R.; Cunningham, S. D.: Phytoremediation of lead-contaminated soils: Role of synthetic chelates in lead phytoextraction. Environ. Sci. Technol. 1997, 31, (3), 800-805.

21. Vassil, A. D.; Kapulnik, Y.; Raskin, I.; Salt, D. E. The role of EDTA in lead transport and accumulation 
by Indian mustard. Plant Physiology 1998, 117, 447 453.

22. Wu, J.; Hsu, F. C.; Cunningham, S. D. Chelateassisted $\mathrm{Pb}$ phytoextraction: $\mathrm{Pb}$ availability uptake, and translocation constraints. Environ. Sci. Technol. 1999, 33, 1898-1905.

23. Begonia, G. B.; Begonia, M. F. T.; Miller, G. S.; Kambhampati, M.: Phytoremediation of metalcontaminated soils: Jackson State University research initiatives. In Metal ions in biology and medicine, Centeno, J. A.; Collery, P.; Vernet, G.; Finkelman, R. B.; Gibb, H.; Etienne, J. C., Eds. 2000; Vol. 6, pp 682-684.

24. Begonia, G. B.; Miller, G. S.; Begonia, M. F. T.; Burks, C. Chelate-enhanced phytoextraction of leadcontaminated soils using coffeeweed (Sesbania exaltata raf.). Bull. Environ. Contam. Toxicol. 2002, 69, (5), 624-654. 37.

25. Shen, Z.G.; Li, X.D.; Wang, C.C.; Chen, H.M.; Chua, H.: Lead phytoextraction from contaminated soil with high-biomass plant species. J. Environ. Qual. 2002, 31, 1893-1900.

26. Turpeinen, R.; Salminen, J.; Kairesalo, T. Mobility and bioavailability of lead in contaminated boreal forest soil. Environ. Sci. Technol. 2000, 34, 51525156.

27. Cao, X.; Ma, L. Q.; Chen, M.; Donald W. Hardison, J.; Harris, W. G. Weathering of lead bullets and their environmental effects at outdoor shooting ranges. J. Environ. Qual. 2003, 32, 526-534.

28. Dushenkov, V.; Kumar, P. B. A. N.; Motto, H.; Raskin, I.: Rhizofiltration: The use of plants to remove heavy metals from aqueous streams. Environ. Sci. Technol. 1995, 29, 1239 - 1245.

29. Lasat, M. M.: Phytoextraction of toxic metals: A review of biological mechanisms. J Environ Qual. 2002, 31, 109-120.
30. Lasat, M. M.; Baker, A. J. M.; Kochian, L. V.: Altered $\mathrm{Zn}$ compartmentation in the root symplasm and simulated $\mathrm{Zn}$ absorption into the leaf as mechanisms involved in $\mathrm{Zn}$ hyperaccumulation in Thlaspi caerulescens. Plant Physiology 1998, 118, 875 - 883.

31. Kayser, A.; Wenger, K.; Keller, A.; Attinger, W.; Felix, H. R.; Gupta, S. K.; Schulin, R. Enhancement of phytoextraction of $\mathrm{Zn}, \mathrm{Cd}$, and $\mathrm{Cu}$ from calcareous soil: The use of NTA and sulfur amendments. Environ. Sci. Technol. 2000, 34, 1778 - 1783.

32. Fuhrmann, M.; Lasat, M. M.; Ebbs, S. D.; Kochian, L. V.; Cornish, J. Plant and environmental interactions: Uptake of cesium-137 and strontium-90 from contaminated soil by three plant species; application to phytoremediation. J. Environ. Qual. 2002, 31, 904-909.

33. Toxnet Hazardous substances data bank. http://toxnet.nlm.nih.gov. Available 08-15-06.

34. Ebbs, S. D.; Lasat, M. M.; Brady, D. J.; Cornish, J.; Gordon, R.; Kochian, L. V.: Phytoextraction of cadmium and zinc from a contaminated soil. $J$. Environ. Qual. 1997, 26, 1424-1430.

35. Lombi, E.; Zhao, F. J.; Dunham, D. J.; McGrath, S. P. Phytoremediation of heavy metal-contaminated soils: Natural hyperaccumulation versus chemically enhanced phytoextraction. J. Environ. Qual. 2001, 30, 1919-1926.

36. Grill, E.; Winnacker, E. L.; Zenk, M. H.: Phytochelatins: The principal heavy-metal complexing peptides of higher plants. Science (Washington, D. C., 1883) 1985, 230, 674-676.

37. Grill, E.; Winnacker, E. L.; Zenk, M. H. Phytochelatins, a class of heavy-metal-binding peptides from plants, are functionally analogous to metallothioneins. Proc. Natl. Acad. Sci. USA. 1987, 84, 439 - 443. 